\title{
THE CORPORATE SOCIAL-FINANCIAL PERFORMANCE LINK: EVIDENCE FROM PAKISTAN
}

\author{
SHAHZAD BUTT \\ Bahria University, Islamabad, Pakistan \\ SAFDAR ALI BUTT \\ Capital University of Science and Technology, Islamabad, Pakistan
}

\begin{abstract}
This empirical investigation has been conducted to constitute a link between corporate social performance and corporate financial performance in Pakistani listed firms. For this purpose the data from seventy listed non-financial firms at KSE from twenty one sectors which are engaged in CSR activities for a period of six years from 2008 to 2013 was employed. The two-stage least square (TSLS) methodology has been used to explore a link between CSP and CFP. The results of study revealed that there is a simultaneous link between social and financial performance. Corporate social performance has been found as positively linked with the previous CFP which supports the slack resources theory. Social performance initiatives taken by the firms have also been found as having a positive relationship with future CFP. Secondly, this study examined the relationship between financial performance and social performance, and the results disclose that there is a positive relationship between CFP and CSP, and the foremostinfluential factor of corporate social performance was found to be size of the firms and the association between firm size and CSP was found as positive.
\end{abstract}

\section{INTRODUCTION}

Corporate Social Performance (CSR) has gained great popularity and attention by various corporations and researchers in the last few decades. The reason of growing attention is that reporting on a corporation's actions has become a dominating factor, as various stakeholders want to know everything about the business in a fair and true manner (Singh, 2014). According to Kim, Park and Wier (2012), CSR has become a need for all kinds of business organizations now and is no longer confined to big companies. Different terms have been used for corporate social performance by corporate managers and researchers such as corporate philanthropy, corporate social responsibility, corporate citizenship, business ethics, socially responsible investment and community involvement. According to World Business Council for Sustainable Development (2002), CSR is "the commitment of business to contribute to sustainable economic development, working with employees, their families and the local community and society at large to improve their quality of life. McWilliams and Siegel (2001) defined CSR as "actions that appear to further some social good, beyond the interest of the firm and that which is required by law". This definition states that CSR is more than just following the law. Tsoutsoura (2004) stated that CSR is viewed, then, as a comprehensive set of policies, practices and programs that are integrated into business operations, supply chains and decision making processes throughout the company and usually include issues related to business ethics, community investment, environmental concerns, governance, human rights, the marketplace as well as the workplace. According to Business for Social Group Responsibility (BSR) "while there is no single, commonly accepted definition of corporate social responsibility, it generally refers to business decision making linked to ethical values, compliance with legal requirements, and respect for people, communities and the environment". Competition has become severe and stiff between domestic and foreign companies to gain more benefits by establishing trust and goodwill between both the government and the society at large and only those companies that attain the trust of the public and behave good corporate citizens will be able to develop these intangible assets into strategic advantages (Ehsan \& Kaleem, 2012). World's top companies' corporate scandals such as Enron and WorldCom with environmental changes also highlighted CSR as one of the core challenges (Silberhorn \& Warren, 2007). Doane (2005) was of 
the view that CSR relates to the implicit expectation from business to provide better environmental and social results without any regulatory framework from government. Stated generally, CSR is the initiative which a corporation takes about its impacts on the community and society. The aim of this study is to establish a link between corporate social performance and corporate financial performance. This study is unique in a sense that it is a bi-directional study, which will examine a simultaneous relationship between CSR and CFP, which will identify the direction of influence, i.e., whether good managerial efforts on CSR will lead to improved financial performance, or a good financial performance will lead to better corporate social performance. Further, this study will also explore the nature of relationship between corporate social performance and firm financial performance. Many researchers studied the relationship between CSP and CFP, but most of the studies have been made in developed nations. In the context of Pakistan, very few studies have been done on CSR which were unidirectional in nature. This study is unique in a sense that it will conduct firm and industry level analysis to gauge the link between the said variables, CSP and CFP, in an emerging economy i.e., Pakistan. This study will also highlight those financial factors which affect corporate social performance, which will eventually guide the firms in this context, and will also assist the prospective investors from abroad in allocating their investments in socially desirable companies.

In Pakistan, both the companies and society have relatively less awareness about their duties and rights with regard to CSR, so Pakistan is lagging behind the western nations in creating awareness of corporate social responsibility benefits in society and firms as well. Then, Pakistan is going through a lot of domestic problems in the form of war against terrorism, energy crises, illiteracy, poor health infrastructure and above all, political and economic uncertainty. Few big local companies and multinational companies like FFC, Nestle, Pakistan Petroleum, Shell, Engro Corporation, ARL, ICI, and Unilever Pakistan are allocating towards CSR. Therefore, it has become very much essential to educate the society and corporations about the long run benefits of adopting CSR programs. Government, firms and people are the three main stakes, which form a society and community and any single stake from these three cannot survive without the backing of other. Pakistan has been undergoing a lot of domestic economic and law and order difficulties along with international issues. This study will provide an understanding to the corporate sector about the various desires of society and how the financial performance can influence the corporate social responsibility activities, so it is very crucial to study the factors which may affect the corporate social performance of firms.

\section{REVIEW OF LITERATURE}

An attempt to examine the relationship between CSP and CFP was made by Cochran and Wood (1984) using new methodologies and ideas. They found the existence of relationship between the two variables with or without age of corporate assets. Another research was carried out by Aupperle, Carroll, and Hatfield (1985) who for the sake of same comparison employed a unique instrument to cater for ideological bias while viewing the relationship between CSP and financial performance of the firm. That instrument was distributed among CEOs of different corporations and conclusion drawn was that CSP was not related to profitability of any company. According to Ullman (1985), there are many variables which can intervene between the CSP and FP, so we should not expect a relationship between these two aspects. McGuire, Sundgren, and Schneeweis (1988) concluded that lagged financial performance is a predictor of better corporate social performance, and CSP does not predict CFP. In a unique attempt to study the relationship between CSR and CFP, Clarkson (1995), instead of doing a fresh study, tried to cover the 70 older notable studies carried out in the past 10 years and ended up in development of a comprehensive analysis of CSP evaluation including a framework and methodologies to be followed in evaluation of CSP. He summarized that firms are more responsive to Stakeholder issues rather then social issues covering society as a whole. Turban and Greening (1997) argued that the corporations which follow proper CSR principles and policies are able to attract and retain employees which help to reduce turnover and training costs. Preston and O'Bannon (1997) argued that social activities involve financial costs, and if a firm spends on social performance activities, it will decrease its financial performance in comparison to its competitors. When it comes to causality,Waddock and Graves (1997) found that CSP depends upon financial performance which supports the Slack Resources Theory, and at the same time financial performance also depends upon social performance, which supported the good management theory, and this simultaneous link is referred as a virtuous circle. Preston and O'Bannon's (1997) study highlighted that there is a positive link between CSP and CFP which, as per the stakeholder theory and CSP-CFP correlations, are best explained by positive synergy hypothesis which supposes that higher level of CSP improves CFP, which yields surplus available funds, which are reinvested to the various stakeholders, which eventually creates a simultaneous link between CSP and CFP, leading to virtuous circle. Balabanis, Phillips, and Lyall (1998) focused on UK market and based their 
conclusion on sample of 56 companies of suitable size. They found very little relation between CSR application and profitability of the firms. They also concluded that consistency was also lacking between them.

Carter, Kale and Grimm (2000) concluded that environmental purchasing is significantly related to both net income and cost of goods sold. This perspective of positive link between corporate social performance and corporate financial performance is based on Stakeholder Theory given by Freeman (1984). Dowell, Hart, and Yeung (2000) studied the effectiveness of Global Environmental standards in comparison to local standards. Their sample was based on US MNE companies considering their market performance. McWilliams and Siegel (2000) tested the association between CSR and financial performance by taking R \& $\mathrm{D}$ as variable for CSR, and their results showed that CSR and $\mathrm{R} \& \mathrm{D}$ are highly correlated and eventually they found that CSR has a neutral effect on profitability. Kind and Lenox (2001) studied 652 US companies to conclude that companies which cause lower level of pollution and gas emissions show better financial performance and the main reasons identified were strategic position and fixed characteristics of the firm. This relationship was also examined by Hillman and Keim (2001), they argued that only concerns for the community has a positive linkage with the firm's profitability.

According to Ruf, Muralidhar, Brown, Janney, and Paul (2001), the inconclusive results of studies which explored a link between CSR and CFP is due to no standardized measure for CSR,no theoretical background, sampling issues, no matching of CSR and CFP variables and methodology issues. Hillman and Keim (2001) also found a virtuous circle between CSP and CFP in their study. Moderated Regression and subgroup analysis were run by Goll and Rasheed (2004) to study the relationship between CSR and CFP. They selected a sample size of 62 firms and 3 item scale questionnaire to measure CSR, while archival information was used for financial performance and environmental impact. They arrived at the conclusion that firms of dynamic environment willing to voluntarily invest in social activities actually show better financial performance. According to Tsoutsoura (2004), CSR is positively related to financial performance, and actual costs of CSR are covered by the benefits, supporting the view that socially responsible corporate performance is associated with a series of bottom-line benefits. Curran (2005) studied the relationship between CSR and CFP by conducting three impressive empirical studies. First of them was an event study evaluating listings on FTSE 4 Good Index, and found no impact on firms for being listed or not on index. The second study found that firms that have small market capitalization, low levels of income statement gearing and are high in respect of net profits reported in any sector have a positive relationship with CSR. The third found out that when faced with investment decisions, those who study the business studies consider social issues. Chand (2006) claimed a strong relationship between CSP and CFP only if looked at from a different angle. After analyzing various past studies on the topic he concluded that if industry type is used as a boundary condition, then every research will end up with confirmatory results. Guenster, Derwall, Bauer, and Koedijk (2006) used eco-efficiency data compiled by Innovest Strategic Value Advisors and financial performance figures from US stock market listings and found that relationship exists between the two. Using a questionnaire for survey of Japanese companies in order to assess the relationship between CSP and CFP, Hino et al (2006) discovered a significant relationship between the two variables. Brammer, Brooks and Pavelin (2006) concluded that firms whose social performance scores were high, their returns were lower; whereas, the firms whose CSP scores are very less, their market performance was excellent, supporting the negative association between CSP and CFP.

According to other school of thought, there is no significant association between CSP and CFP. Barnett and Salomon (2006) found that association between CSP and CFP is neither positive nor negative; instead they found it as curvilinear. Artiach, Nelson, and Walker (2007) discovered that those companies that are leading CSP operators exhibit much better financial performance then those firms that do not follow CSP practices; thus, confirming the view that those companies that invest in CSP have always been better as far as financial performance is concerned. The relationship of CSR and stock prices was studied in the context of Italian markets by Fiori et al (2007), who pointed out that in the absence of generally accepted standards in Italy, the general investor perception was relatively low about importance of social issues. An attempt was made by Hill, Ainscough, Shank, and Manullang (2007) to measure the relationship between CSP and CFP across the different continents namely US, Europe and Asia. They did find the relationship between the two, but with investor biases as to how do they figure SRIs as factor in investment decisions.

The relationship between CSR and CSP was also examined by Pirsch, Gupta, and Grau (2007) and they argued that the existence of a firm will depend upon its ability to attain its economic and non-economic (social initiatives). The relationship between the CSR and CFP was also investigated by Brammer and Millington (2008), they used Tobin's Q (market to book value) to measure the effect of financial performance. They asserted that if firms focus on the relations with society, 
which will in turn improve their image in market, then various CSR dimensions will lead to improvement in financial performance of firms. Bouquet and Deutsch (2008) tried to study the relationship between CSP and ability of firms to achieve required sales in foreign countries. They found that those firms that are active in following social activities are leading those who are still at intermediate level of CFP. Goukasian and Whitney (2008) selected the top 100 KLD companies to conduct an event study, to examine the relationship between CSR and CFP by selecting year 2000 as the event year, while the total time period was 6 years. They confirmed that those companies who are perceived as socially responsible are able to maintain healthy relations with their shareholders, and can afford to pay higher returns on shareholder's investments. According to Lee (2008), the studies on CSR revolved around two areas. From theoretical perspective, scholars initially focused on ethical behavior and then they shifted their arguments towards implied performance based studies. An attempt was made by Lin, Yang, and Liou (2009) to study the same association in Taiwan firms. They stated that corporate social performance has a positive impact on the long run financial performance of firms.

Banerjee et. al. (2009) viewed CSR with perspective of Corporate Governance and its impact on firm's performance. They used CG score that was obtained from CRISIL and used that as a proxy for quality of Governance. They chose Tobin's Q as proxy for financial performance and adopted a fixed affect regression analysis to draw their conclusion. They concluded that positive relationship exists between CG score obtained and value of the firm. Another study was conducted by Kacperczyk (2009), they concluded that three areas namely environmental concerns, concern for the society and diversity related problems are positively associated with firm's financial performance. Fauzi and Idris (2009) measured the relationship between CSP and CFP, but this time by control variable of Industry type and by moderating the variables of company size and leverage. Their results displayed that only financial leverage has the ability to affect the relationship between the two main variables, but commented that this relationship may well only be spurious. A well designed questionnaire was used by Fauzi and Idris (2009) to study the relationship between CSP and CFP, and they based their research on two theories, i.e., Slack Resource Theory and Good Management Theory.

Covering the angles of economy, society and environmental performance in performance of the company, they found the positive relationship between the two variables. Another important study was carried out by Barnea and Rubin (2010), who claimed that one of the main reasons of over investment in CSR activities could be the wishes of managers and large stakeholders who want to be known as responsible citizens. They analyzed the CSR rating of the corporations with the perspective of ownership and capital structures. Sample size was of 3000 largest US companies, and they were to be branded as either socially responsible or irresponsible (SR or SI). Conclusion drawn was that ownership structures are negatively related to CSR score although they found no relationship of institutional ownership and CSR score. Another research to study the relationship between the CSR and CFP was carried out by Blazovich and Smith (2010) with one addition, i.e., they also used Market Value Premium as performance measure in addition to traditional ones, e.g., profitability or Cost of Capital, and showed no direct relationship between Market value and CSR activities when control for last year equity yielded. The relationship between CSP and CFP was also studied in the context of Korean market by Choi, Kwak, and Choe (2010) with sample size of 1122 Korean companies. They used the model used by Akinpar et al. (2008) including an index of equally weighted CSR and Index of Stakeholder weighted average CSR, and used ROA, ROE and Market to Book ratio (Tobin's Q) in order to measure CFP. They found that CFP was related to index of Stakeholder weighted average CSR only.

Pleasantly this relationship between CSP and CFP has also been tested in the context of Pakistani markets by Hamid, Akash, Asghar, and Ahmad (2011). They discovered no relationship between CSP and CFP as far as Pakistani companies are concerned. In order to assess the impact of CSR on financial performance, Inoue, Kent, and Lee (2011) analyzed the previous studies made by various scholars. They concluded inconsistent results. According to Bashir, Hassan, and Cheema (2012), a good CSR program has a positive impact on the employees of the firm, and it provides them mental relaxation. Ehsan and Kaleem (2012) also made an attempt to study the relationship between corporate social responsibility and financial performance from Pakistani perspective. They concluded a positive relationship between CSR and FP, which revealed positive social behavior of Pakistani firms. Windsor (2013) pointed out that CSR literature mainly consisted of four different thoughts. The first two schools of thought were related to CSR attractiveness. The first thought related to a comparison between those who favored CSR and those who were against the CSR. The next area was about the minimum and maximum threshold about the CSR spending. The next view point was linked with the argument that whether CSR should be considered as ethical or strategic oriented, and then another thought which emerged from literature suggested replacing CSR with that of corporate citizenship. Lee, Park, and Lee (2013) were of the view that socially 
responsible firms creates a positive insight among their employees, which in turn improves their commitment and performance. An effort was made to capture the relationship between CSR and FP of Pakistani firms by Javed, Syed, Lodhi, and Malik (2013).They found mixed results, the first two parts of Carroll's model, Economic and Legal responsibility were positively related while the last two parts, Ethical and Discretionary responsibility were negatively associated. On the basis of the above discussion the following hypothesis can be formulated:

\section{Hypothesis 1. There is a positive impact of CSP in $R O A$. \\ Hypothesis 2. There is a positive impact of CSP on $R O E$. \\ Hypothesis 3. There is a positive impact of ROA on CSP. \\ Hypothesis 4. There is a positive impact of ROE on CSP.}

\section{RESEARCH METHODOLOGY}

The literature review has identified six variables to explore and establish a link between corporate social performance and financial performance of Pakistani firms. For the purpose of this study, sample size comprised of 70 non-financial public limited companies (PLC) listed on Karachi stock exchange, and analysis was based on six year data from 2008-2013. The seventy companies selected for the study belonged to twenty two sectors of KSE. The data on corporate social responsibility was taken from annual reports of companies. The data on CSR of firms that produce sustainability reports separate from annual reports was taken from their corporate sustainability reports covering CSR. To assess the CSR involvement of firms, we studied the annual reports of sample firms and a checklist of 20, used by Muttakin \& Khan (2014) in their study in Bangladesh. They followed the checklist constructed by Haniffa and Cooke $(2002,2005)$ and Ghazali (2007), and developed a modified checklist including the items relevant to Bangladeshi companies. Since, there is a similarity between Bangladeshi and Pakistani culture, so we also used that checklist to assess the information. Figure 1 shows the checklist items considered in this study.

A dichotomous procedure iswas applied whereby a company was awarded 1 if an item included in the checklist was disclosed in annual report otherwise 0 . CSR index was derived by computing ratio of actual scores awarded to the maximum possible score attainable for items appropriate to that firm. CSR index used by Haniffa and Cooke (2002) given as following was used:

$$
C S R_{j} \text { Index }=\sum_{t=1}^{n j} x j j / N_{j}
$$

Where,

CSRj Index $=$ Corporate Social Responsibility Index for jthfirm

FIGURE 1

CSR items checklist

\begin{tabular}{ll}
\hline Item No. & Items Name \\
\hline I & Community Involvement \\
& \\
II & Environmental Information \\
III & Employee information
\end{tabular}

IV Product and service information Items Description

1. Charitable donations and subscriptions

2. Sponsorships and advertising

3. Community program (health and education)

1. Environmental policies

1. Number of employees/human resource

2. Employee relations

3. Employee welfare

4. Employee education

5. Employee training and development

6. Employee profit sharing

7. Managerial remuneration

8. Workers' occupational health and safety

9. Child labor and related actions

1. Types of products disclosed

2. Product development and research

3. Product quality and safety

4. Discussion of marketing network

5. Focus on customer service and satisfaction

6. Customer award/rating received

1. Value added statement 
$\mathrm{N}_{\mathrm{j}}=$ Number of items expected for $\mathrm{j}^{\text {th }}$ firm, where $\mathrm{N} \leq 20$ $\mathrm{x}_{\mathrm{ij}}=1$, if ith items are disclosed for firm $\mathrm{j}, 0$ if otherwise, so that $0 \leq \mathrm{CSR}_{\mathrm{ij}} \leq 1$

Two stage least square (TSLS) methodology was used for data analysis to capture the relationship between CSP and CFP; as in cases of over identified equations, the twostage least squares (TSLS) method is the most commonly used method. In regression equations, CSP and ROA/ ROE were considered as endogenous variables.

$\mathrm{CSP}_{\mathrm{it}}=\beta_{0}+\beta_{1}(\mathrm{ROA})_{\mathrm{it}}+\beta_{2}(\mathrm{AGE})_{\mathrm{it}}+\beta_{3}(\mathrm{FSIZ})_{\mathrm{it}}+\beta_{4}(\mathrm{RISK})$ ${ }_{\text {it }}+\beta_{5}(\mathrm{CSP})_{\mathrm{it}-1}+\beta_{4}(\mathrm{SGR})_{\mathrm{it}}+\varepsilon_{\mathrm{it}}$

$\mathrm{CSP}_{\mathrm{it}}=\beta_{0}+\beta_{1}(\mathrm{ROE})_{\mathrm{it}}+\beta_{2}(\mathrm{AGE})_{\mathrm{it}}+\beta_{3}(\mathrm{FSIZ})_{\mathrm{it}}+\beta_{4}(\mathrm{RISK})$ it $+\beta_{5}(\mathrm{CSP})_{\mathrm{it}-1}+\beta_{4}(\mathrm{SGR})_{\mathrm{it}}+\varepsilon_{\mathrm{it}}$

$\mathrm{ROA}_{\mathrm{it}}=\beta_{0}+\beta_{1}(\mathrm{CSP})_{\mathrm{it}}+\beta_{2}(\mathrm{AGE})_{\mathrm{it}}+\beta_{3}(\mathrm{FSIZ})_{\mathrm{it}}+\beta_{4}(\mathrm{RISK})_{\mathrm{it}}$ $+\beta_{5}(\mathrm{ROA})_{\mathrm{it}-1}+\beta_{4}(\mathrm{SGR})_{\mathrm{it}}+\varepsilon_{\mathrm{it}}$

$\mathrm{ROE}_{\mathrm{it}}=\beta_{0}+\beta_{1}(\mathrm{CSP}) \mathrm{it}+\beta_{2}(\mathrm{AGE})_{\mathrm{it}}+\beta_{3}(\mathrm{FSIZ})_{\mathrm{it}}+\beta_{4}(\mathrm{RISK})_{\mathrm{it}}$ $+\beta_{5}(\mathrm{ROE})_{\mathrm{it}-1}+\beta_{4}(\mathrm{SGR})_{\mathrm{it}}+\varepsilon_{\mathrm{it}}$

Where:

$\mathrm{CSP}_{i \mathrm{it}}=$ Corporate social performance for firm $\mathrm{i}$ in period t., $\mathrm{ROA}_{\mathrm{it}}=$ Return on Assets for firm $\mathrm{i}$ in period t, $\mathrm{ROE}_{\mathrm{it}}=$ Return on Equity for firm i in period t, $\mathrm{CSP}_{\mathrm{it}-1}$ $=$ Corporate social performance for firm $\mathrm{i}$ in period ${ }_{\mathrm{t}-1}$, $\mathrm{AGE}_{\mathrm{it}}=$ Age of firm for firm $\mathrm{i}$ in period $\mathrm{t}, \mathrm{FSIZ}_{\mathrm{it}}=$ Size of firm for firm $i$ in period $t, \mathrm{SGR}_{\mathrm{it}}=$ Growth rate of firm for firm $i$ in period $t$, RISK $_{\text {it }}=$ Leverage for firm $i$ in period t, $\varepsilon_{\text {it }}=$ Error term.

\section{RESULTS AND DISCUSSION}

This study intended to establish a link between corporate social performance and corporate financial performance, i.e., whether CSP is dependent upon on CFP or CFP is dependent upon CSP. To check this, twostage least square method (TSLS) was applied for panel of 70 firms and six years data from 2008-2013 was used for the analysis. Descriptive statistics are tabulated in table 1 . The average size of the sample was 16.25 . As size is reported in millions, to smoothen the data, Log (asset) was used. Standard deviation of size was 1.53 which means that the mean can deviate 1.53 in either direction. As the standard deviation value was not so abnormal; therefore, data posed a normal behavior. The mean value of corporate social performance in the study was 0.47 and its standard deviation is 0.21 , as this value was not abnormal, so data represented a normal pattern. The mean value of age in the study was 3.24 and its standard deviation is 0.55 . As this value is not abnormal, so data represented a normal pattern. The average size of the risk was 1.61 and standard deviation of risk was 1.94 which means that the mean can deviate 1.94 in either direction. As the standard deviation value is not so abnormal, therefore data posed a normal behavior. The mean value of ROA in the study was 11.92 and its standard deviation was 3.32 , which means that the mean can deviate 3.32 in either direction. As this value is not abnormal, so data represented a normal pattern. The same pattern exists for remaining variables as well.

Two models were used to explore the link between CSP and CFP. The table 2 relates to the results in which CSP has been taken as dependent variable and it has been regressed on various factors taken as instruments including ROA which were used as proxy to measure firm's financial performance. According to the table, the explanatory power of the equation 1 in modell is 0.87 , which reflects that $87 \%$ variation in dependent variable is attributable to the independent variables. The value of F-Stat is highly significant which shows model is fit. Here, ROA has been taken as a proxy to measure financial performance, and to check its impact on corporate social performance.

The results showed that ROA affects the corporate social performance positively and this relationship is significant at $5 \%$ level. This result signifies that if a firm is earning more profits then it will allocate more funds towards corporate social activities of the society. In modern era of responsible corporations, it is evident that the more a corporation is profitable; there will be paucity of resources towards CSR activities. The results are in line with Ullmann (1985), Waddock and Graves (1997) and Choi et al (2010). According to Slack resources theory, those firms which have slack resources available with them due to better financial performance can freely invest in socially desirable projects.

TABLE 1

Descriptive Statistics

\begin{tabular}{lccccccc}
\hline & FSIZE & CSP & AGE & RISK & ROA & ROE & SGR \\
\hline Mean & 16.250 & 0.476 & 3.249 & 1.618 & 11.928 & 26.389 & 0.163 \\
Median & 16.255 & 0.458 & 3.238 & 1.190 & 8.890 & 21.130 & 0.150 \\
Maximum & 19.841 & 1.000 & 4.158 & 9.800 & 25.230 & 110.160 & 1.650 \\
Minimum & 12.611 & 0.000 & 1.386 & -2.230 & -17.610 & -36.770 & -0.623 \\
Std. Dev. & 1.530 & 0.217 & 0.550 & 1.949 & 3.320 & 5.852 & 0.263 \\
\hline
\end{tabular}


TABLE 2

\begin{tabular}{lcc}
\hline $\begin{array}{l}\text { Dependent Variable: CSP } \\
\text { Name of Variable }\end{array}$ & Coefficient & t-statistic \\
\hline Constant & 0.05 & $4.23 * *$ \\
ROA & 0.13 & $1.99 * *$ \\
AGE & 0.01 & 0.41 \\
FSIZ & 0.08 & $2.21^{* * *}$ \\
RISK & -0.21 & -0.87 \\
SGR & 0.02 & 0.12 \\
CSP(-1) & 0.91 & $7.06^{*}$ \\
Adj. R Square: 0.87 & & \\
F Stat: 367 (0.00) & & \\
\hline$* * * * *$ and * indicate 5 per cent, 1 per cent and 10 per \\
cent level of significance.
\end{tabular}

Eventually, this helps in creating good image and repute among the community with which the firms have to interact and this view is also aligned with the results. Further analysis revealed that lagged value of corporate social performance is positively associated with CSP, and this relation was highly significant. CSR is not just one time activity; rather, it is a behavior which society or community, where the corporation functions, demands from the organization. Results manifest that previous period CSR has an impact on current period spending; therefore, it can be argued that corporations do have history of community development. As corroborated by Choi et al (2010) and Gang Fu et al. (2012), previous spending of corporation on community does effect the current spending. Firm size and age were positively linked with CSR, but only size of firm showed significant impact.

As corporations grow in size, its resources increases, which, in result, enhance the slack resource of the organization. These slack resources are used to develop the community besieging the corporation. Leverage was used as a proxy of the firm risk; the more leverage a company has, the more risk it will have. Risk showed negative relation with CSR. According to debt covenants hypothesis, debt holders barred the organization to take part in any welfare distribution, till the debt is fully repaid. Therefore, more leverage will bound the organization to first payoff the liabilities and then distribute any share of its income to its besieged. Sales growth was positively related with the social performance of organization, but statistically the impact was insignificant. Risk was negatively related with corporate social performance and their relationship was not significant as well. The study of Muttakin and Khan (2012) also confirms the result. However, the relationship is eminent that more risk will lessen the investment in societal affairs.
TABLE 3

\begin{tabular}{lcc}
\hline $\begin{array}{l}\text { Dependent Variable: CSP } \\
\text { Name of Variable }\end{array}$ & Coefficient & t-statistic \\
\hline Constant & 0.06 & $1.51^{*}$ \\
ROE & 0.2 & $2.23 * *$ \\
AGE & 0.08 & 0.28 \\
FSIZ & 0.18 & $2.04 * *$ \\
RISK & -0.24 & $-1.32 *$ \\
SGR & 0.04 & 0.25 \\
CSP(-1) & 0.92 & $7.19^{* * *}$ \\
Adj. R Square: 0.86 & & \\
F Stat: 366 (0.00) & & \\
\hline ***, ** and * indicate 1 per cent, 5 per cent and 10 per \\
cent level of significance.
\end{tabular}

Table 3 shows the results in which CSP has been taken as a dependent variable, and various factors have been taken as instruments which also include ROE, which has been used as proxy to measure financial performance. The explanatory power of the equation 2 (model 1) is 0.86 which shows that $86 \%$ variation in CSP is due to variables taken and the value of F-stat is also significant which reflects model fitness. Here in table 2, ROE has been considered as a proxy to measure CFP, and to check its effect on CSP. The results suggest that ROE has a positive association with CSP, and their relationship was found significant at 5\% level. This result shows that if a firm is doing well and strongly on financial side, then it will have sufficient resources to allocate for social causes, which ultimately will help in building better relations with the community.

The studies of Preston and O'Bannon (1997); Orlitzky, James, Schmidt, and Rynes (2003); Rim Makni et al. (2008); Ehsan and Kaleem (2012) also support this result. According to Slack resources theory, the more the resources are at the corporation disposal, the more investment will be in social performance. Lagged value of corporate social performance was found to be positively associated with CSP and their relation was also significant. This result reveals that investing on socially conducive activities in last year does create a positive effect on current year CSP. The study of Choi et al (2010) and Gang Fu et al. (2012) also support these findings. Age of the firm and corporate social performance were found to be positively linked but their relation was insignificant. Firm size was positively associated with social performance and their relation was also significant. This result highlights that as the firm grows in size, it is inclined to spend more on the welfare of the society. Risk was found to be negatively related with corporate social performance and their relationship was not significant as 
well. It can be argued that more risk alter the priorities of the organization, hence we observe less investment in social activities. Sales growth and CSP were found to be positively linked, but there relation was insignificant.

\section{TABLE 4}

\section{Dependent Variable: ROA}

\begin{tabular}{lcc} 
Name of Variable & Coefficient & t-statistic \\
\hline Constant & 0.53 & 0.37 \\
CSP & 8.30 & $3.62 * * *$ \\
AGE & 0.07 & $2.11^{* *}$ \\
FSIZ & 0.09 & $1.99 * *$ \\
RISK & 0.55 & $2.37 * *$ \\
SGR & 8.38 & $4.80^{* * *}$ \\
ROA(-1) & 0.65 & $8.45^{* * *}$
\end{tabular}

Adj. R Square: 0.60

F Stat: $84(0.00)$

***, ** and $*$ indicate 1 per cent, 5 per cent and 10 per cent level of significance.

Table 4 discloses the results in which ROA has been considered as dependent variable. The explanatory power of the equation 3 is 0.60 which shows that $60 \%$ variation in ROA is due to variables taken as instruments, and the value of F-stat is also significant which reflects model fitness. In these results, ROA has been taken as proxy to capture financial performance and CSP effect on ROA has been analyzed. It is evident from the results that CSP is positively linked with the ROA and the relationship between these two variables was also found significant. The results found a simultaneous linkage, which suggests that financial performance does depend upon social performance initiatives taken by the management, and these results are in conformity with good management theory, stakeholders theory, social contract theory and legitimacy theory, which state that a firm's performance depends upon meeting the expectations of stakeholders well in advance before any concerns and problems relating to stakeholders may arise, which depicts proactive attitude towards stakeholders. Lagged value of return on assets was found to have a positive linkage with return on assets, and their relationship was significant as well, suggesting that better financial performance in previous year leads to good performance in the current year as well. Social contract theory asserts that business firms are important members of the society, and they should be as responsible in their business dealings as other members of society exhibit in their dealings. Legitimacy theory signifies the importance of CSR to firms as a form of getting repute and relations with society with the motive of adopting an image that will legitimize their operations and conduct, inclined in favor of various stakeholders.
Studies of McGuire et al (1988); Donaldson and Preston (1995); Waddock and Graves (1997); Tsoutsoura (2004) also confirm the results. Size of the firm was found to have a positive association with ROA. This result suggests that as the firms become larger in size, their financial performance also improves. Risk was found to be positively linked with return on assets; this asserts that as the firm uses more debt, its financial performance should also improve. This result is in alignment with the signaling theory which states that if future prospects of the firm are bright, then firms tend to issue debt instead of equity. Sales growth and ROA were found to have a positive and a significant association. This result depicts that the firms whose sales are on the rising side than the last year will tend to show better financial performance. The same pattern of positive relation exist between age and ROA according to the results, which exhibits that as the corporations get old, they start developing relations with the outside world and environment, and they tend to spend more on the community social causes.

\section{TABLE 5}

\section{Dependent Variable: ROE}

\begin{tabular}{lcc} 
Name of Variable & Coefficient & t-statistic \\
\hline Constant & -17.97 & $-2.20 * *$ \\
CSP & 62.25 & $4.92 * * *$ \\
AGE & 0.37 & $1.98^{* *}$ \\
FSIZ & 1.19 & $2.74 * *$ \\
RISK & 5.94 & 1.36 \\
SGR & 21.20 & $2.10^{* *}$ \\
ROE(-1) & 0.25 & $1.92 *$ \\
Adj. R Square: 0.35 & & \\
F Stat: 30.58 (0.00) & & \\
***, ** and * indicate 1 per cent, 5 per cent and 10 per \\
cent level of significance.
\end{tabular}

Table 5 states the results in which ROE has been considered as dependent variable and various factors have been taken as instruments which also include CSP, which has been used as proxy to measure corporate social performance. The explanatory power of the equation 4 (model 2) is 0.35 which shows that $35 \%$ variation in ROE is due to variables taken as instruments, and the value of F-stat is also significant which reflects model fitness. Here, in table 5, ROE has been considered as a proxy to measure CFP and the effect of CSP on ROE has been tested. The results suggested that ROE has a positive association with CSP and their relationship was also found significant. The results again reflect that financial performance is dependent upon corporate social investments undertaken by firms, and these results are as per the stakeholder theory, good management theory and 
social contract theory as well. The studies of Choi et al (2010); Tsoutsoura (2004) also support these findings. Size of the firm was found to have a positive link with ROE. This result suggests that as the firms become larger in size, their financial performance also improves. Risk was found to be positively linked with return on equity; this asserts that as the firm uses more debt, its financial performance should also improve. This result is in conformity with the signaling theory of capital structure, which states that if future prospects of the firm are bright, then firms tend to issue debt instead of equity. Sales growth and ROE were found to have a positive and significant association. This result depicts that the firms whose sales are on the rising side than the last year, will tend to show better financial performance. Lagged value of return on equity was found to have a positive association with return on equity, but their relationship was found insignificant. Age of the firm was found to have a positive and significant linkage with ROE, which depicts that the established firms are inclined to invest more favorably towards societal betterment causes and wellbeing ventures.

\section{CONCLUSION AND RECOMMENDATIONS}

There are two aspects of this study, first one is related to identify and establish a link between CSP and CFP, either CSR is predictor or consequence of financial performance, and secondly to identify the relationship between corporate social performance and financial performance, and to determine the financial factors which cause the CSP, in case CSP is consequence of CFP. The study was conducted by taking data covering from 2008-2013. To establish a link between corporate social performance and corporate financial performance, method of two-stage least square (TSLS) was applied and used. Empirical evaluation and analysis reflect that corporate social performance is both a predictor and consequence of firm financial performance. The thorough discussion is being elaborated below.

In establishing a link between CSP and CFP, firstly it was found that corporate social performance of firms is dependent upon their financial performance, and this finding is as per the slack resources theory, which states that firms which have slack resources available with them due to better financial performance can freely invest in socially desirable projects. Eventually, this helps in creating good image and repute among the community with which the firms have to interact. These findings suggest that Pakistani firms tend to make more investments in community and social welfare, as they earn more due to better performance on financial side and this will have a strong positive impact on building a favorable image within the society.

Furthermore, while establishing a link between CSP and CFP, this study also found a simultaneous linkage which manifests that financial performance does depend upon social performance initiatives taken by the management. Good management theory, stakeholders theory, social contract theory and legitimacy theory support these findings, which state that a firm's performance depends upon meeting the expectations of stakeholders well in advance before any concerns and problems relating to stakeholders may arise, which depicts proactive attitude towards stakeholders. So this study has concluded that there exists a simultaneous link between CSP and CFP, which means that whichever variable is chosen as dependent variable, the effect is positive and it can be interpreted that relationship is bidirectional between CSP and CFP, means that improved CFP leads to improved spending on CSR activities, and proactive initiatives taken on CSP will result in better financial performance.

Secondly, this study explored the relationship between financial performance and social performance, and the results highlight that there exists a positive association between CFP and CSP. This supported those past studies which manifested positive association (e.g., Auperle, et al., 1985; Waddock \& Graves, 1997; Choi et al., 2010). The leading determining factor of CSP has been found as size of the firm, and the relationship between size and corporate social performance has been found as positive. A good number of firms in the sample are well known and have large size, which helps in making a conclusion that large firms tend to have more resources, which give them greater liberty to invest in community welfare and society well-being projects to gain strategic benefits in the form of improved relations and image with different stakeholders. Risk showed negative relation with CSR, as according to debt covenants, debt holders imposes restrictions on the organizations to take part in any welfare distribution, till the debt is fully repaid.

On the basis of the study conducted some recommendations can be set forth. First, the firms should devote and invest consistently for the wellbeing and uplift of the society to enjoy cordial relations with the community. According to social contract theory, firms are important member of society and in this capacity they should display same level of morality for the society as other members are expected to. Second, government should encourage and acknowledge the firms engaged in doing CSR investments and should reward them so that they may be more motivated towards community welfare areas. Government should also provide reduction in taxes to those corporations which help and contribute for the community welfare.

There are some limitations to the results of this study. This study has concentrated on the disclosures which have been made by companies in their annual financial reports. However, the management may have adopted other 
means of communication to highlight their initiatives and investments on the social causes and community welfare like print media and internet, so future research should also incorporate these other modes of communication while analyzing CSR performance of firms. Secondly, in this study CSR index has been computed which is based on five broader categories relating to CSR disclosures. The CSR index calculated here might not have fully incorporated all the corporate social responsibility practices. Therefore, future research should take into account more insights of CSR areas.

\section{REFERENCES}

Artiach, T., Nelson, D. \& Walker, J. (2007). Financial Performance and Corporate Social Responsibility. Proceedings of the conference of UQ Business School at the University of Queensland, <www. afaanz.org/openconf/2007/papers/222.pdf>

Aupperle, K.E., Carroll, A.B., \& Hatfield, J.D. (1985). An empirical examination of the relationship between corporate social responsibility and profitability. Academy of Management Journal, 28(2), 446-463.

Balabanis, G., Phillips, H. C., \& Lyall, J. (1998). Corporate social responsibility and economic performance in the top British companies: are they linked?. European Business Review, 98(1), 25-44.

Banerjee, A., Gokarn, S., Pattanayak, M., \& Sinha, S. K. (2009). Corporate governance and market value: Preliminary evidence from Indian companies. Standard and Poor's Financial Services, 200(12), 2.

Barnea, A. \& Rubin, A. (2010). Corporate Social Responsibility as a Conflict between Shareholders. Journal of Business Ethics, 97, 71-86.

Barnett, M. L. \& Salomon, R. M. (2002). Unpacking social responsibility: the curvilinear relationship between social and financial performance. Academy of Management Proceedings, Working Paper-SIM: B1.

Bashir, R., Hassan, A., \& Cheema, F.-E.-A. (2012). Impact of corporate social responsibility activities over the employees of the organizations: An exploratory study. Journal of Management and Social Sciences, 8(2), 11-21.

Blazovich, J. L., \& Smith, M. (2010). Ethical corporate citizenship: Does it pay?. Research on Professional Responsibility and Ethics in Accounting, Forthcoming.

Bouquet, C., \& Deutsch, Y. (2008). The impact of corporate social performance on a firm's multinationality. Journal of Business Ethics, 80(4), 755-769.

Brammer, S. \& Millington, A. (2008). Does it pay to be different? An analysis of the relationship between corporate social and financial performance. Strategic Management Journal, 29(12), 1325-1343.

Brammer, S., Brooks, C., \&Pavelin, S. (2006).Corporate social performance and stock returns: UK evidence from disaggregate measures. Financial Management, 35(3), 97-116.

Carter, C.R., Kale, R., \& Grimm, C.M. (2000). Environmental purchasing and firm performance: An empirical investigation. Transporation Research Part E: Logistics and Transportation Review, 36(3), 219-228.

Chand, M. (2006). The Relationship between Corporate Social Performance and Corporate Financial Performance: Industry Type as a boundary condition. The Business Review, Cambridge, 5(1), 240

Choi, J., Kwak, Y. \&Choe, C. (2010). Corporate Social Responsibility and Corporate Financial Performance: Evidence from Korea. Australian Journal of Management, 35(3), 291-311.

Clarkson, M. (1995). A Stakeholder Framework for Analysing and Evaluating Corporate Social Performance. Academy of Management Review, 20(1), 92-118.

Cochran, P.L., \& Wood, R.A. (1984). Corporate social responsibility and financial performance. Academy of Management Journal, 27(1), 42-56.

Doane, D. (2005). Beyond corporate social responsibility: minnows, mammoths and markets. Futures, 37(2), 215-229.

Donaldson, T. \& Preston, L. E. (1995). The Stakeholder Theory of the Corporation: Concepts, Evidence, and Implications. Academy of Management Review, 20(1), 65-91.

Dowell, G., Hart, S., \& Yeung, B. (2000). Do corporate global environmental standards create or destroy market value?. Management Science, 46(8), 10591074.

Ehsan, S., \& Kaleem, A. (2012). An empirical investigation of the relationship between Corporate Social Responsibility and Financial Performance (Evidence from Manufacturing Sector of Pakistan). Journal of Basic and Applied Scientific Research,2(3),2909-2922.

Fauzi, H., \& Idris, K. (2009). The relationship of CSR and financial performance: New evidence from Indonesian companies. Issues in Social and Environmental Accounting, 3(1).

Freeman, R. E. (2010). Strategic management: A stakeholder approach. Cambridge University Press.

Ghazali, N. A. M. (2007). Ownership structure and corporate social responsibility disclosure: Some 
Malaysian evidence. Corporate Governance, 7(3), 251-266.

Goll, I. \& Rasheed, A. A. (2004). The Moderating Effect of Environmental Munificence and Dynamism on the Relationship between Discretionary Social Responsibility and Firm Performance. Journal of Business Ethics, 49, 41-54.

Goukasian, L., \& Whitney, L. K. (2008). Corporate Socially Responsible Firms Perform Well! Evidence from Financial and Operating Performances. Evidence from Financial and Operating Performances (May 20, 2008).

Guenster, N., Derwall, J., Bauer, R., \& Koedijk, K. (2006). The economic value of corporate ecoefficiency.[Cited 15 Feb 2007].

Hamid, K., Akash, R. S. I., Asghar, Md. \& Ahmad, S. (2011). Corporate social performance, financial performance and market value behavior: An information asymmetry perspective. African Journal of Business Management, 5(15), 63426349.

Haniffa, R. M., \& Cooke, T. E. (2002). Culture, corporate governance and disclosure in Malaysian corporations. Abacus, 38(3),317-349.

Haniffa, R. M., \& Cooke, T. E. (2005). The impact of culture and governance on corporate social reporting. Journal of Accounting and Public Policy, 24(5), 391-430.

Hill, R. P., Ainscough, T., Shank, T., \& Manullang, D. (2007). Corporate social responsibility and socially responsible investing: A global perspective. Journal of Business Ethics, 70(2), 165-174.

Hillman, A.J., \&Keim, G.D. (2001).Shareholder value, stakeholder management and social issues: What is the bottom line? Strategic Management Journal, 22,125-139.

Inoue, Y., Kent, A., \& Lee, S. (2011). CSR and the bottom line: Analyzing the link between CSR and financial performance for professional teams. Journal of Sport Management, 25(6), 531-549.

Javed, M., Saeed, R., Lodhi, R.N., \& Malik, Q.Z. (2013). The relationship between corporate social responsibility and firm financial performance: A case of Pakistan. Journal of Basic and Applied Scientific Research, 3(11), 34-45.

Kim, Y., Park, M. S., \& Wier, B. (2012). Is earnings quality associated with corporate social responsibility? The Accounting Review, 87(3), 761-796.

Lee, E. M., Park, S.-Y., \& Lee, H. J. (2013). Employee perception of CSR activities: Its antecedents and consequences. Journal of Business Research, 66(10), 1716-1724.

Lee, M. D. P. (2008). A review of the theories of corporate social responsibility: Its evolutionary path and the road ahead. International Journal of Management Reviews, 10(1), 53-73.

Lin, C. H., Yang, H. L., \& Liou, D. Y. (2009). The impact of corporate social responsibility on financial performance: Evidence from Business in Taiwan. Technology in Society, 31(1), 56-63.

McGuire, J. B., Sundgren, A., \& Schneeweis, T. (1988). Corporate Social Responsibility and Firm Financial Performance. Academy of Management, 31(4), 854-872.

McWilliams, A., \& Siegel, D. (2000). Corporate social responsibility andfinancial performance: correlation or misspecification? Strategic Management Journal, 21(5), 603-609.

Muttakin, M. B., \& Khan, A. (2004). Determinants of corporate social disclosure: Empirical evidence from Bangladesh. Advances in Accounting, incorporating Advances in International Accounting. http://dx.doi.org/10.1016/j. adiac.2014.03.005

Orlitzky, M., James, G., Schmidt, F. L. \&Rynes, S. L. (2003). Corporate Social and Financial Performance: A Meta-analysis. Organization Studies, 24, 403- 441.

Pirsch, J., Gupta, S., \& Grau, S. L. (2007). A framework for understanding corporate social responsibility programs as a continuum: An exploratory study. Journal of Business Ethics, 70(2), 125-140.

Preston, L.E., \& O'Bannon, D.P. (1997). The corporate social-financial performance relationship: A typology and analysis. Business and Society, 36(4), 419-429.

Ruf, B. M., Muralidhar, K., Brown, R. M., Janney, J. J., \& Paul, K. (2001). An empirical investigation of the relationship between change in corporate social performance and financial performance: A stakeholder theory perspective. Journal of Business ethics, 32(2), 143-156.

Silberhorn, D., \& Warren, R. C. (2007). Defining corporate social responsibility: A view from big companies in Germany and the UK. European Business Review, 19(5), 352-372.

Tsoutsoura, M. (2004). Corporate social responsibility and financial performance. Center for responsible business.

Turban, D.B., \& Greening, D.W. (1997).Corporate social performance and organizational attractiveness to prospective employees. Academy of Management Journal, 40(3), 658-672.

Ullmann, A. A. (1985). Data in search of a theory: A critical examination of the relationships among social performance, social disclosure, and economic performance of US firms. Academy of Management Review, 10(3), 540-557. 
Waddock, S.A., \& Graves, S.B. (1997). The corporate social performance-financial performance link Strategic Management Journal, 18(4), 303-319.

Windsor, D. (2013). Corporate social responsibility and irresponsibility: A positive theory approach. Journal of Business Research, 66(10), 1937-
1944.

World Business Council for Sustainable Development, E. C. (2002). The Business case for sustainable development: Making a difference towards the Earth summit 2002 and beyond. Corporate Environmental Strategy, 9(3), 226-235. 